No doubt $P M L A$ 's multiple-submissions policy is well-intended, but it is not realistic in today's world of fax machines, Internet, voice mail, and the like, where communication is virtually instantaneous and decisions in areas outside academic publishing are made immediately. Who can wait a year, or two years, after sending an article to a refereed journal before submitting it to another? Academics who will perish unless they publish must get their writing into print quickly. Multiple submissions are simply a "sellers" attempt at self-preservation in the treacherous academic job market. While art may be long and scholarship longer, contemporary academic publishing is yet a longer and an even more excruciating process, apparently derived from, and more appropriate to, the hand lettering of manuscripts in the medieval era.

Censorship is hardly the issue. Quick response is. Businesses do not, could not, function as academic journals do. Only in journals is an indefinite response time still tolerated today. It's a luxury that few faculty members scrambling for promotion and tenure can afford.

\section{MICHAEL HOLDEN}

Delaware State University

\section{To the Editor:}

Typically for this egocentric time, the new editor of $P M L A$ cannot believe "that the purpose of publication was ever principally and altruistically the benefit of readers" (11n2). Such is Domna C. Stanton's reaction to Ursula M. Franklin's nostalgic essay "Does Scholarly Publishing Promote Scholarship or Scholars?," which finds that crude careerism is now the rule of the day.

We are not dealing with mutually exclusive motives. Of course one writes with hope of reputation and its benefits (sometimes very solid benefits), but those who do not put the reader and the subject matter first are liable to stumble as they dash toward their professional goals. While a true scholar may be defined as a person who is not in a hurry, the research of these numerous others may, as may their conclusions, be quick. Their style is likely to be obfuscatory, for being understood risks objections. Since they do not really care about the advancement of knowledge, they react with not always muted rage (in, for example, the Forum) when corrections or suggestions for expansion are offered; any questions raised are treated as personal insults, despicable and malicious assaults on their amour propre, and monkey wrenches in their careers. An impersonal interest in getting things right is outside their conception.

\section{EDWARD LE COMTE North Egremont, $M A$}

\section{The Paradox of Censorship}

To the Editor:

Agreeing with Paul de Man, Michael Holquist contends in "Corrupt Originals: The Paradox of Censorship" (109 [1994]: 14-25) that censorship encourages parabolic and oppositional readings that "specifically resist ... what the censor wants" (22). My reading of his essay and of the essays that he introduces supports his contention. According to one of Holquist's uses of the word "censorship" (he says that an editorial decision not to print de Man's "Resistance to Theory" was censorship), the Literature and Censorship issue of PMLA "censors" the arguments in favor of censorship. Although Holquist is correct to say that censorship is "ineluctable," he merely concludes that it is therefore difficult to know "which of its effects to oppose" (22). For him censorship is always "repressive" and "vicious" $(16,18)$. People whose utterances are censored are always "victims" $(16,17)$.

Holquist renders these totalizing judgments while refusing to distinguish between different forms and occasions of censorship-by refusing, one blushes to say, to define his term. It seems that Holquist is against all the various acts throughout history that have been called by someone or other "censorship." At one point "censorship" is even personified-it "loathes" poetry (19). I can report that I do not oppose all that has been called censorship, and I do not loathe poetry. There is at least one exception to Holquist's universalizing judgments.

Certainly there are many repressed questions that his highly censored view of censorship might prompt in the resisting reader. What does it mean to rail against censorship for being repressive in a context in which one has acknowledged that we are always within power - that censorship and power are inescapable facts of social life? Why do the authors in the Literature and Censorship issue inevitably treat the censored author as a victim, without ever considering the ways audiences can be victimized by unscrupulous texts? Why are all the "victims" of censorship chosen 